\title{
Exploring the Nexus: Terrorism and Economic Growth in Pakistan
}

\author{
Saad Nisar ${ }^{1}$ \\ Dr. Rab Nawaz Lodhi ${ }^{2}$ \\ Kiran Farooq ${ }^{3}$ \\ M. Qatadah Idrees ${ }^{4}$
}

\begin{abstract}
Education has different meanings as per different approaches. The quality in education is a complex and multicultural process. This study was conducted to check the Quality in higher Education. Four higher institutions were taken as sample. Out of which two were from public sector. The theoretical frame work consisted of the dependent variable which was, "Quality in Higher Education", and the independent variables which were Management, Faculty, Infrastructure, Research Facilities and Evaluation Criteria. Overall results showed that majority (73\%) respondents were in view that there is quality in education in higher education institutions. The most important factor which helps to maintain quality in higher education is the evaluation criteria in examinations (responded 23\%). The lack of proper infrastructure is the main problem of education institutions (responded 35\%). The above results show that quality in higher education is an essential tool to boost up the education sector of any country.
\end{abstract}

Keywords: growth rate, inflation, trade balance, terrorism

\section{INTRODUCTION}

\section{Background of the Study}

The rise or fall in the GDP growth rate is very important for any country of the world, because it heavily affects employment rate and revenue collection. Many scientists and researchers studied GDP measuring variables and found different relationship between them (Nitsch 2004, Anderson 2015 etc). A stream of suicide bomb attacks or terrorist attacks started in Asia after 9/11. Some people connect it with religious and many people think that terrorists have no religion. A fraction of mass considers terrorist attacks motivated by religion and others disagree to it.

Terrorism and economic growth has inverse relationship between them. If the growth rate of the country is gradually increasing year by year, there are more chances of declining unemployment and generating employment in that country. Some people create unrest in other countries for their own interest to decrease the growth rate. If a country assures life security and its law and order system is active then the foreign investors invest in that country. Terrorism is one of the main indicators which affect the foreign investment, business cycle, as well as growth rate of the country. Terrorism causes threats to human life at different levels and affects their way of earning. Terrorism has posed serious problems to the economy of Pakistan. It causes social and political instability where risks are always involved for the international investors to invest in a terror stricken country.

\footnotetext{
1- Saad Nisar is a M.Phil Scholar at Institute of Business and Management, University of Engineering and Technology, Lahore, Pakistan, saadnisar143@gmail.com

2- Dr. Rab Nawaz Lodhi, is an Assistant Professor, Institute of Business and Management, University of Engineering and Technology, Lahore, Pakistan

3- Kiran Farooq is a Lecturer, Institute of Business and Management, University of Engineering and Technology, Lahore, Pakistan 4- M. Qatadah Idrees, works at Institute of Business and Management, University of Engineering and Technology, Lahore, Pakistan 
Apart from man power, war on terrorism costs huge amount of money which results into unemployment. Living standard of the people is worsened and poverty rate results into less income per capita. Increasing inflation and price hike further add to the miserable situation. Less income per capita means lesser access to basic necessities, health and quality educational facilities. As terrorism directly affects the consumption companies lose their clients. A study is conducted to show the effect of terrorism on consumption and saving. By empirical analysis it is showed that there is negative impact of consumption and saving on the terrorism activities Eckstein and Tsiddon (2004). They also found that rise in terrorist activities reduces the economic activity. Terrorism also affects the budget of the country. Many countries are spending a large amount against terrorism. In Nigeria Government is spending more budgets on anti-terrorist attacks and policy makers are consuming more energy to decline the number of terrorist attacks in the country. Pakistan is also spending a large budget on anti-terrorism. The neighboring country India is also facing terrorist activities. After Mumbai attacks on 26 Nov 2008 India received a grant of \$ $4.5 \mathrm{~m}$ from the US government for the fiscal year 2011 to fight against the terrorism.

The Indian government is still engaged to construct or build a national computer database association over the 14000 police station of the country which will concede the police officers for the first time to search the doubtful people based on IRIS scans or fingerprints. According to the American intelligence report, America is financing a large amount of its budget against terrorism in all over the world. She is financing $\$ 16.6$ billion annually against terrorism (http://www.pewresearch.org/fact-tank/2013/09/11/u-s-spends-over-16-billion-annually-on-c ounter-terrorism/). According to the economic survey 2014/2015 Pakistan has lost a large amount of $\$ 107$ billion to cease or decrease the terrorist activities between 2001/2022 and 2014/2015. Pakistan has established an Anti Terrorist Force with the cooperation of Turkey and a total of 1,500 posts for the ATF were recruited by the Punjab government and a risk allowance of Rs. 50000 would be given to each person of the force after training. The rate of foreign debt is also affected by terrorism resulting in under developing countries remain under developed. Government has been devising new economic laws according to the changing situations at the national and international level. Recently, after Peshawar attack, Government has taken serious steps and passed serious laws to get rid of this terrorism dilemma.

Figure 1: Terrorist Attacks from period 2003-2013

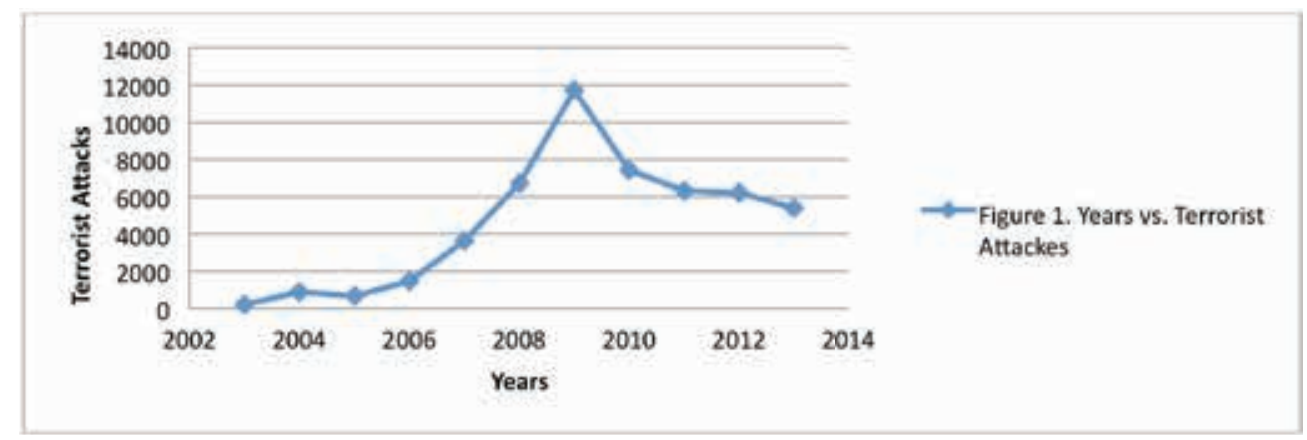

Source: South Asian Terrorism Port 
Figure 2: Growth rate of the country from period 2003-2013

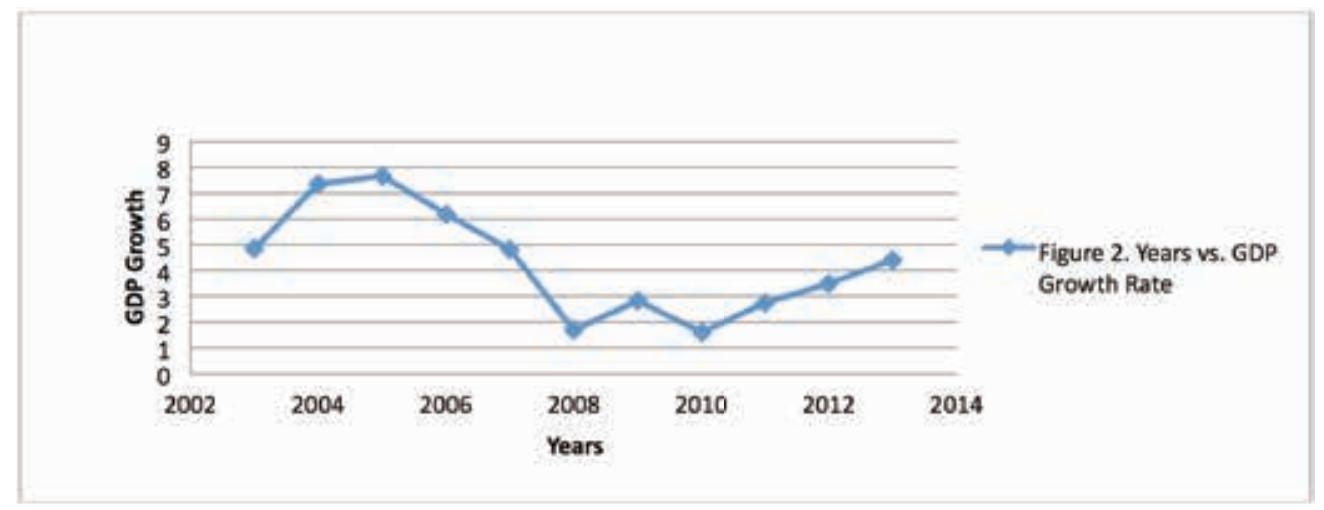

Source: World Development indicator

It is clear from the figure 1 and figure 2 that with the passage of time terrorist attacks are increasing and the growth rate (in percentage) of the country is decreasing.

\section{LITERATURE REVIEW}

Different authors have different point of view about the relationship between economic growth and terrorism in a country. Abadie (2004) analyzed the main determinants of terrorism at country level. He explained that for poorer countries the risk of terrorism is significantly high and also suggested that geographic factors are important to sustain terrorist activities. Araz- Takay et al. (2009) explored the macroeconomic effect of terrorism on economy and they found significant and diverse impact of terrorism on economic growth. Bader (2015) studied on the terrorism and expatriates. He gathered the data from 121 expatriate managers who work in risky countries where terrorism is common phenomenon. He found that the performance of the single expatriate workers was better than the workers which have family along with them.

Bravo and Dias (2006) explored the nexus between international trade and terrorism. They found that there was negative nexus between terrorism and international trade. They have also found the relationship between terrorism and international trade in less developed countries. They covered the data from 1997 to 2004 and concluded that high rate of terrorist attacks occurred in less developed economies that had low dependence on international trade. Chani et al. (2011) evaluated the effect of poverty on inflation. They gathered the data from 1972-2008 and applied Auto Regressive Distributive Lag bound testing approach to co-integration to find a long run impact of poverty on inflation and the results clearly confirm that they have positive and significant impact between them.

Chesney, Reshetar and Kamran (2011) found the impact of terrorism on commodity market, bond market and behavior of stock. They gathered the data from 25 countries over an eleven years period of time by applying different methods, GARCH-EVT approach, non-parametric methodology, an event study approach. Results clearly showed that terrorism was the main reason of financial market crashes. Against the terrorism risk this research can also be used for investors' portfolio diversification. Collier et al. (2003), report that the terrorism has the economic consequences of diverting the foreign direct investment from the country. Moreover, it is destroying and redirecting public investment funds to security or limiting trade 
and infrastructure development. Kenya is being spent a huge amount of money in order to reduce the terrorism in the country.

Enders and Sandler (2000) studied terrorism and its threats. In their research terrorism is the use of extra-normal, designed and calculated threat to achieve political and religious aims and objectives by frightening a large public. Enders and Sandler (1996) studied the relationship between terrorism and net foreign direct investment to explore the impact of terrorism on net foreign direct investment and they used VAR in Greece and Spain to found relationship between them. The results concluded that terrorism declined the net foreign direct investment by $11.9 \%$ and $13.5 \%$ respectively in these countries.. Fatima, Latif and Chugtai (2014) found the negative significant impact of terrorism on GDP growth rate. They used 7 years data of terrorism and GDP growth rate and applied regression analysis through SPSS. They concluded that in Pakistan when the terrorist activities increased the growth rate decreased significantly. Gassebner and Luechinger's (2011) analyzed the effect on poverty due to terrorism activities. For this purpose they used proxy variable infant mortality. They saw that there was negative relationship between them. They also found that there was minor effect of economic growth on terrorist activities.

Gillani et al. (2009) explored the impact of unemployment, inflation and poverty on crime. They covered the data from 1975-2009 and applied granger causality test to explored the nexus between them and the results clearly revealed that there is positive relationship between these independent variables and dependent variable and crime was caused by unemployment, inflation and poverty in Pakistan. Gupta et al. (2002) analyzed the effect on conflict and terrorism on the low and middle income countries. The results told that high rate of inflation and low economic growth hike the conflict and they also had is negative impact on investment and tax revenue. Ismail and Amjad (2014) found the determinants of terrorism in Pakistan by applying Johnson co-integration technique they found long run relationship between the variables. They found that unemployment, inflation, income inequality, political rights, literacy level, GDP per capita and poverty are the major determinants of terrorism.

Kinyanjui (2014) analyzed the impact of terrorism on foreign direct investment by using the secondary time series data from 2010 to 2013 for Kenya. The results clearly revealed that there is negative impact of terrorism on foreign direct investment in Kenya. Knight et al. (1996) evaluated the nexus between military expenditure and Gross Domestic Product to analyzed the impact of military expenditure on GDP. For this purpose they used time series and cross sectional data and found that an increase in $2.2 \%$ of military expenditure will lead to decrease in gross domestic product by $2 \%$. Krieger and Meierriecks (2011) covered the data of 65 countries from 1975 to 1999 and studied about the relation of divisional income on terrorist attacks. They discussed that there was a strong positive correlation between them and noted that income inequality was an important predictor of the terrorist attacks. Malik and Zaman (2013) explored the effect of terrorism on macroeconomic factors i.e. political instability, poverty, population and price level and economic growth. They covered the data 1975-2011 from different sources applied Granger Causality test and concluded that there was negative impact of terrorism on macroeconomic factors.

Mirza and Verdier (2008) found the relationship of international trade and transnational terrorism. They covered data from different sources from period 1968-1999 and found that there was negative nexus between transnational terrorism nad bilateral trade flows. Nasir et al. (2008) explored the nexus between terrorist activities and economic development in Pakistan. The results clearly argued that there was no relation between them. Nasir (2012) found the relationship between terrorism and military expenditures. He used per capita GDP as proxy 
variable of military expenditures. He found significant and positive relationship between per capita GDP and terrorism. Nitsch and Schumacher (2004) explore the nexus between international trade, volume of trade and terrorism. They collected the data of more than 200 countries from the period of 1960-1993. They found than there was negative impact of terrorism on international trade. They found compelling evidence that terrorist actions reduced the volume of trade by 4\%.Piazza (2006) hypothesized that inequality, poverty, unemployment, poor economic development were the main factors for increase in terrorist attacks but the results significance of relationship between economic growth and terrorism.

Polachek (1980) analyzed relationship between conflict and international trade. For this purpose he collected the cross sectional data of 30 different countries. He found that there was negative relationship between conflict and terrorism. Due to terrorism, trade was reduced by $20 \%$.

Richardson (2011) evaluated the effect of unemployment, population size and higher education on terrorism by gathering the data from 56 countries between 1980 and 2008 to find relation between them. The study told that there was strong correlation of unemployment and population size with terrorism while there was no significant association of higher education with terrorism. Noar (2006), Eckstein and Tsiddon (2004) analyzed the relationship of terrorist activities with current consumption and saving and discovered that rise in terrorist activities declined the economic activities.

Schock (1996) developed a hypothesis by connecting the political opportunistic and economic discontent framework. By using multiple regression analysis the empirical findings clearly indicated that there was positive connection between economic separatist potential and inequality on political violence and hence on terrorism in weak regions. Shah and Faiz (2015) found the connection between terrorism and foreign direct investment. They covered the period from1980-2012 and used panel data of SAARC countries and found that terrorism was the main thread of reducing the FDI from the countries. Sandler (2006) found that there was opposite relationship between terrorism on economy but this relationship is statistically significant in OECD countries.

There are many studies which have established that internal conflicts reduce economic growth significantly. Studies over the last decade have entrenched that infrastructure can have significant impact on reducing the economic growth within a conflict-ridden country (e.g., Hoeffler and Collier, 2004; Collier and Sambanis, 2002; Collier et al., 2003). Shahbaz (2013) analyzed the impact of inflation and growth rate on terrorism. He used 34 years data from different sources and found negative relation between growth and terrorism and positive between inflation and terrorism. Shahbaz and Shabbir (2011) found the relationship between inflation and terrorism by using annual data of Pakistan from 1971-2010. By applying auto regressive distributive lag bound test to integration they showed that there was positive relation between terrorism and inflation. They suggested that government should take necessary steps to control the inflation in order to reduce the terrorism.

Many authors explored many researches to find out major determinants of fall in GDP growth rate. Our basic gap of this research is model gap. We established a new model to check the nexus between GDP growth rate with the inclusion of inflation and trade balance. We are also finding major determinant of terrorist attacks and the reasons of increasing in violence in Pakistan. 


\section{Study Objective}

The study object is to conduct the research by using time series data from different sources. Terrorism affects many variables but we used growth rate, CPI inflation and trade of Pakistan to explore the nexus between them. Many scientists gave indecisive results by using different sample periods, data of different countries, variables and different econometric techniques. Fatima (2014) used 7 years' time series data of terrorism and economic growth to find the nexus and found that there was significant and negative relationship between them. The entire study shows the causal relationship between terrorism and economic growth of the country and how it is harmful for the development of any country. Asia is the targeted location for maximum terrorist attacks in the World. After 9/11 terrorism started in Asia and spread all over the countries. Our study indicates that there is negative relationship between terrorism and economic growth of Pakistan.

\section{Hypotheses}

H1: There is negative and significant relationship between terrorism and economic growth.

$\mathrm{H} 2$ : There is positive and significant relationship between terrorism and inflation.

H3: There is negative and significant relationship between terrorism and trade balance of Pakistan.

\section{Model}

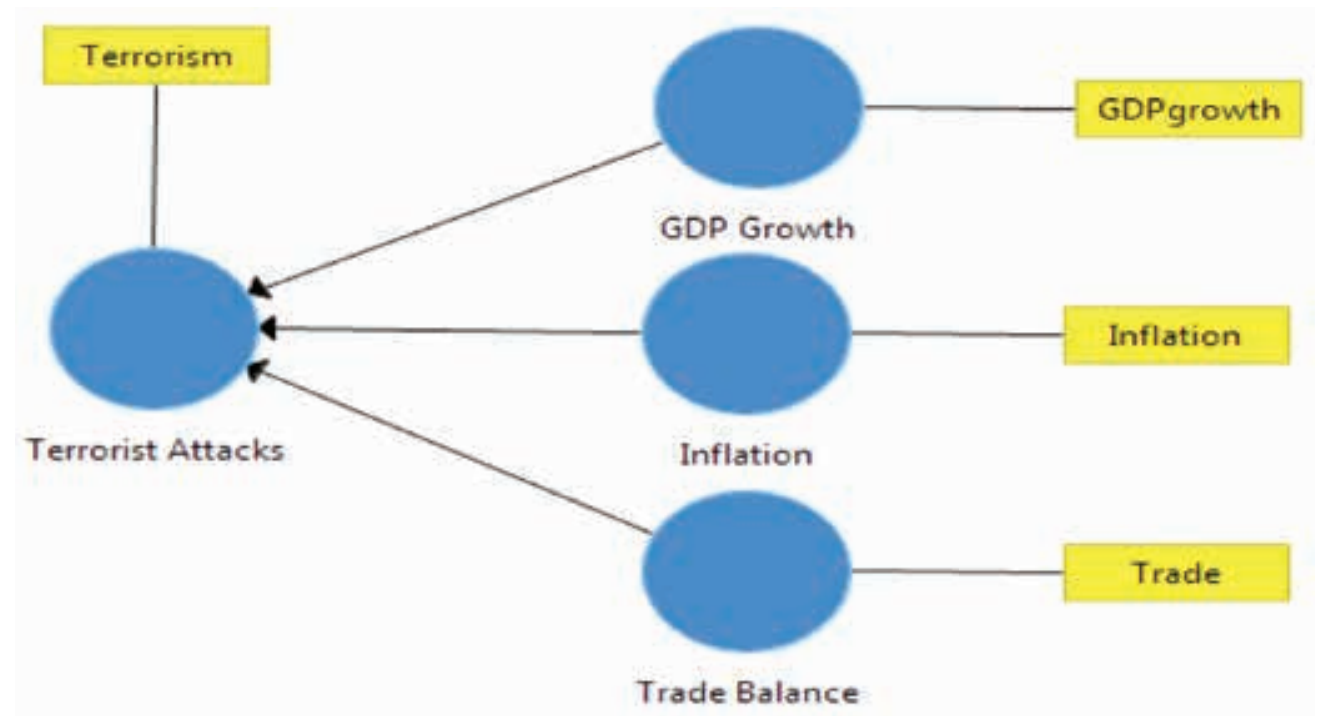

Our model is clearly showing one dependent variable terrorist attacks and three independent variables GDP growth rate, Inflation and trade balance. We are showing three major determinants of terrorist attacks. 


\section{RESEARCH METHODOLOGY}

In this section, we will briefly explain the dynamic behavior between economic growth, inflation, trade and terrorism. Sandler (2006), Shahbaz (2013), Fatima (2014), told that there is negative and significant relationship between terrorism and economic growth. Shahabaz and Shabir (2011) evaluated the positive nexus between inflation and terrorism. Nitsch and Schumacher (2004) and Mirza and Verdier (2008), found that international trade is responsible for terrorism in the country. We have incorporated trade and inflation to investigate the causal relationship between terrorism and economic growth of the Pakistan. According to previous researches terrorism decreases the economic growth by frightening the minds of people Enders and Sandler (2000). Terrorism also creates security issues in a country which lead to decline in the foreign direct investment. As the investment decreases growth rate also decreases. So the terrorism has effects on the economic growth directly and indirectly. We are using partial least square analysis on these variables by using smart PLS software to show the significance of relationship between variables.

\section{Data Source}

The data is collected through different sources. The data of GDP growth rate is collected through World Bank the data of WDI Pakistan, while the data of terrorism is collected through South Asian Terrorism Port (SATP) and the data of inflation rate is collected through economic survey of Pakistan and the data of trade balance is gathered through The Global Enabling Trade Report of Pakistan. The data taken is of period 2003-2013.There are also many studies which are conducted on terrorism which shows that terrorism has significant negative impact on GDP growth rate (Sandler 2006, Fatima 2014). In this paper terrorism is taken as dependent variable and GDP growth rate, inflation and trade balance are taken as independent variables to explore the nexus of growth rate, inflation, and international trade on terrorism.

Table No. 1

\begin{tabular}{lc}
\hline Years & Terrorist attacks \\
\hline $2003-2004$ & 189 \\
$2004-2005$ & 863 \\
$2005-2006$ & 648 \\
$2006-2007$ & 1471 \\
$2007-2008$ & 3598 \\
$2008-2009$ & 6715 \\
$2009-2010$ & 11701 \\
$2010-2011$ & 7435 \\
$2011-2012$ & 6303 \\
$2012-2013$ & 6211 \\
$2013-2014$ & 5379 \\
\hline
\end{tabular}

Source: South Asian Terrorism Port 2003-2013 


\section{Equation}

The empirical investigation of our research is based on multiple regression model.

$\mathrm{Y}=\beta 0+\beta 1 \mathrm{gr}+\beta 2$ inf $+\beta 3 \mathrm{tr}+\mathrm{e}$

Where,

$\mathrm{Y}=$ Number of terrorist attacks faced by Pakistan

gr= Annual GDP growth rate (in \%) of Pakistan

inf $=$ Inflation rate $($ percentage increase $)$

$\operatorname{tr}=$ Trade Balance (in million rupees)

\section{Quality Content}

Inflation is also a determinant of terrorism. According to Economic Survey of Pakistan 2009-10 the inflation rate was $13.3 \%$, while it was $22.3 \%$ in last fiscal year destroying the savings of the public but in Economic Survey of Pakistan 2011-12 rate of inflation was about $11 \%$.U.S policy makers righted a positive causal connection between poverty and terrorism. From the previous study, we also find that there is a positive association between inflation and poverty Chani et al. (2008).

Table No. 2

Descriptive Statistics

\begin{tabular}{lrrr}
\hline & Mean & Std. Deviation & $\mathbf{N}$ \\
\hline Terrorism & 4592.0909 & 3589.86592 & 11 \\
GDPgrowth & 4.3360 & 2.09902 & 11 \\
Inflation & 10.1862 & 4.58921 & 11 \\
TradeBalance & -10807.4545 & 4889.58940 & 11 \\
\hline
\end{tabular}

We evaluated mean and standard deviation of the variables which are used in our research. Table No.3 shows the mean and standard of the variables. The table shows that there were mean 4592 terrorist incidents occurred in every year from 2003-2013. The mean GDP growth rate of Pakistan is $4.3 \%$ mean inflation is $10.18 \%$ and mean trade balance is -10807.4545 million Pakistani rupees from 2003-2013.

\section{Quality Content}

Partial least square analysis is applied through smart PLS software. Our findings are as follows

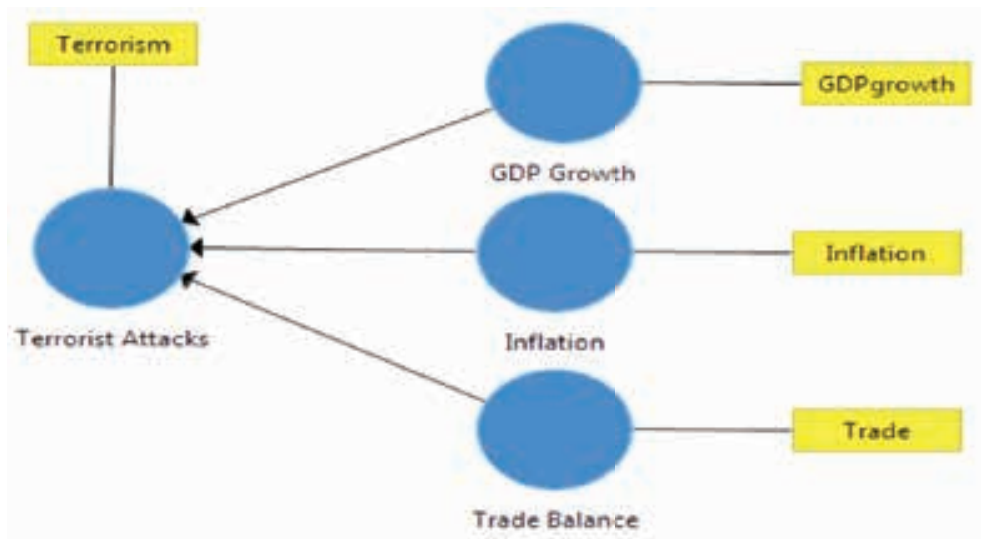


We applied PLS Algorithm technique in smart PLS to show the effect of three independent variables on terrorism. In the above picture the results clearly argues that if other factors remain constant there is $100 \%$ increase in GDP growth rate it will reduce the terrorist attacks rate by $80.9 \%$. It means that there is negative nexus between terrorism and GDP growth rate. If other factors remain the same 1 unit increase in inflation rate increase the terrorist attacks by 0.686 units and if other factors remain the same 1 unit increase in trade balance reduce the terrorist attacks by 0.540 units. The value of R2 is 0.717 means that there is strong effect of independent variables on terrorism. If terrorism is changes by $100 \%$ then $71.7 \%$ changes are due to GDP growth rate, inflation and trade balance.

To check the significant relationship we used bootstrapping technique in smart PLS. the results are as followed in table no3.

Table No. 3

\begin{tabular}{llllll}
\hline & $\begin{array}{l}\text { Original } \\
\text { Sample }(\mathrm{O})\end{array}$ & $\begin{array}{l}\text { Sample } \\
\text { Mean }(\mathrm{M}) \\
(\mathrm{STDEV})\end{array}$ & $\begin{array}{l}\text { Standard } \\
\text { Deviation }\end{array}$ & $\begin{array}{l}\text { T Statistics } \\
(\text { IO/STDEVI) }\end{array}$ & P Values \\
\hline $\begin{array}{l}\text { GDP Growth } \\
->\text { Terrorist }\end{array}$ & -0.809 & -0.829 & 0.091 & -8.916 & 0.000 \\
$\begin{array}{l}\text { Attacks } \\
\text { Inflation } \\
->\text { Terrorist }\end{array}$ & 0.686 & 0.712 & 0.121 & 5.667 & 0.000 \\
$\begin{array}{l}\text { Attacks } \\
\text { Trade Balance } \\
->\text { Terrorist }\end{array}$ & -0.540 & -0.526 & 0.266 & -2.029 & 0.043 \\
Attacks & & & & & \\
\hline
\end{tabular}

The table is showing negative and significant nexus between terrorism and GDP growth rate: $\mathrm{p}$-value is less than 0.05 and $\mathrm{t}$ value is less than -1.96 it means that there is negative and significant relation between them. On the behalf of these results we accept the alternate hypothesis H1. There is positive and significant relationship between terrorism and inflation where $\mathrm{p}$-value is less than 0.05 and $\mathrm{t}$ value is greater than 1.96 so we accept the alternate hypothesis $\mathrm{H} 2$. There is also negative nexus between terrorist attacks and trade balance and their impact is also significant so we accept the alternate hypothesis H3.

\section{Graph1: Terrorism and economic growth of Pakistan}

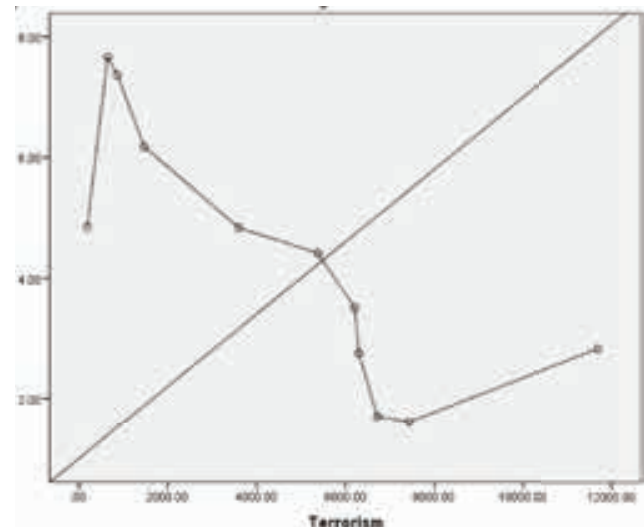


The graph1 shows that there is an increasing trend of terrorist activities resulting in a decreasing trend of growth rate of Pakistan. Terrorism played a vital role to reduce welfare, foreign direct investment, trade and economic growth in the country. It affects the growth of the country directly and indirectly. Pakistan is a peaceful country and growing very fast by increasing the interest of foreign investors. China, USA and many countries are investing in Pakistan and the government of Pakistan convinces them by solving the security issues.

\section{CONCLUSION AND SUGGESTIONS}

The main aim of terrorists is to destroy the economy of the country. Every country in the world is facing many challenges internally. Pakistan is controlling many challenges like she is obstructing extremism and militancy, resolving energy crisis, spreading education, creating jobs to the unemployed people and limiting terrorist attacks. Terrorism creates problems for by all the developed countries as well as under developed countries, however, this phenomenon is most common in the developing countries. It affects the annual GDP, foreign direct investment, tourism industry, trade as well as growth rate of a country. The federal government and military are fighting against terrorism to establish peace in Pakistan.

The existing literature on this research reveals many factors like law and order situation of political instability, income inequality, poor-enforcement of economic policies, high unemployment and corruption which affect intensity of terrorism in a country. These aspects affect the economy of a country directly and inversely by breaking the confidence of local and foreign investors, decreasing foreign direct investment and adversely affecting financial markets. This leads to lower economic growth, higher unemployment and increased poverty. This research evaluated the short run impact of inflation, trade balance and economic growth on terrorism in Pakistan and also report the nexus between them in which terrorism is a major issue.

This paper indicated that there is negative impact of growth on terrorism. There impact is significant. Pakistan is a growing economy. China and other countries are investing here and foreign direct investment is increasing and it will lead Pakistan to a developed state in future. Our study also indicated that there is a strong positive nexus between terrorism and inflation and there is negative impact of trade balance on terrorism. This research ignored the variables such as unemployment by Richardson (2011); democracy by following Piazza (2008); that can be helpful to show their effect on terrorism. A proper defense policy should be made by the policy makers in such a way that reduces the terrorism and country meets economic boom.

Our military is fighting against terrorism from many years, and to control the hold of terrorist our army started operation zarb e azab on 15 june 2014 and it is an effective operation but its cost may exceed 1.3\$ billion (Pakistan Finance Minister Ishaq Dar 19 Feb 2015). It is duty of state to take effective decisions and solve the security problems to decrease the fear of terrorism in the minds of people. According to the US report on terrorism 'Pakistan is on the top list of the countries which is alert against terrorism and has decreased terror attacks."' 


\section{RECOMMENDATIONS}

After reviewing the whole research researchers evaluated that government should make effective decisions to control the inflation and terrorism because they have positive and significant relation among them. Terrorism has negative effect on economic growth of a country.

- In the situation of policy appliances, the government of Pakistan must take necessary steps to control the inflation not only because it is unfavorable for economic growth but also it has negative effects on the economic growth in Pakistan.

- The government of Pakistan must create more employment opportunities for their citizens.

- The policy makers should make policies to increase investment opportunities, health facilities and build a good relation between the people of Pakistan especially the people of FATA and Baluchistan by creating job quota for them.

- Government should start large scale power projects, build roads to create interest of the locals as well as foreign investors and the fruits of economic growth must be given to every person of the country. For this purpose government should create new institutions which are responsible for providing access to education, health facilities, employment opportunities and build a good relation between people and the government.

- Government should decrease poverty and special allowance should be given to the poorest people because poverty and inflation have positive relation Chani et al. (2011) also there is positive nexus between poverty and crime Gillani et al. (2009).

\section{REFERENCES}

Abadie, A. (2004). Poverty, political freedom, and the roots of terrorism. nber working paper series, $1-15$

Araz-Takay, B., Arin, K. P., \& Omay, T. (2009). The endogenous and non-linear relationship between terrorism and economic performance: turkish evidence. Defence and Peace Economics, 20(1), 1-10.

Bader, B., Berg, N., \& Holtbru“ gge, D. (2015). Expatriate performance in terrorism-endangered countries: The role of family and organizational support. International Business Review .

Bravo, A. B., \& Dias, C. M. (2006). An empirical analysis of terrorism: deprivation, islamism and geopolitical factors. Defence and Peace Economics, 17 (4), 329-341.

Chani, M. I., Pervaiz, Z., Jan, S. A., Ali, A., \& Chaudhary, A. R. (2011). Poverty, inflation and economic growth: empirical evidence from Pakistan. Munich Personal RePEc Archive Paper No.34290 .

Chesney, M., Reshetar, G., \& Kamran, M. (2011). The impact of terrorism on financial markets: An empirical study. Journal of Banking and Finance, 35, 253-267.

Collier, P., Elliott, L., Hegre, H., Hoeffler, A., Reynal-Querol, M., \& Sambanis, N. (2003). Breaking the Conflict Trap: Civil War and Development Policy. A World Bank Policy Research Report .

Enders, W., \& Sandler, T. (2000). Is Transnational Terrorism Becoming More Threatening? A Time-Series Investigation. Journal of Conflict Resolution, 44 (3), 307-332. 
Enders, W., \& Sandler, T. (1996). Terrorism and foreign direct investment in Spain and Greece. Kyklos, 49 (3), 331-352.

Fatima, M., Latif, M., \& Chugtai, S. F. (2014). Terrorism and its Impact on Economic Growth: Evidence from Pakistan and India. Middle-East Journal of Scientific Research, 22 (7), 1033-1043.

Gassebner, M., \& Luechinger, S. (2011). Lock, stock, and barrel: a comprehensive assessment of the determinants of terror. Public Choice, 149, 235-261.

Gillani, S. Y., Rehman, H. U., \& Gill, A. R. (2009). Unemployment, poverty, inflation and crime nexus: cointegration and causality analysis of pakistan. Pakistan Economic and Social Review, 47 (1), 79-98.

Gupta, S., Clements, B., \& e. a. (2002). Fiscal consequences of armed conflict and terrorism in low- and middle-income countries. IMF Working Paper.

Ismail, A., \& Amjad, S. (2014). Determinants of terrorism in Pakistan: An empirical investigation. Economic Modelling, 37, 320-331.

Kinyanjui, S. (2014). The Impact of Terrorism on Foreign Direct Investment in Kenya. International Journal of Business Administration, 5 (3), 148-157.

Knight, M., Loayza, N., \& Villanueva, D. (1996). The peace dividend : military spending cuts and economic growth. IMF Staff Papers, 43 (1), 1-44.

Krieger, T., \& Meierrieks, D. (2011). Does income inequality lead to terrorism? Public Choice, 147, 3-27.

Malik, Z., \& Zaman, K. (2013). Macroeconomic consequences of terrorism in Pakistan. Journal of Policy Modeling, 35, 1103-1123.

Mirza, D., \& Verdier, T. (2008). International trade, security and transnational terrorism: Journal of Comparative Economics, 36, 179-194.

Nasir, M., Arif, A., Rehman, F. U., \& Tariq, M. S. (2008). Terrorism and economic growth: a case study of Pakistan. GCU Economic Journal, 41(2).

Nasir, M., Rehman, F. U., \& Orakzai, M. (2012). Exploring the nexus: Foreign aid, war on terror, and conflict in Pakistan. Economic Modelling, 29, 1137-1145.

Nitsch, V., \& Schumacher, D. (2004). Terrorism and international trade:. European Journal of Political Economy, 20, 423-433.

Piazza, J. A. (2006). Rooted in Poverty? Terrorism, Poor Economic Development, and Social Cleavages. Terrorism and Political Violence, 18, 159-177.

Polachek, S. W. (1980). Conflict and trade. Journal of Conflict Resolution, 24, 55-78. 
Richardson, C. (2011). Relative Deprivation Theory in Terrorism: A Study of Higher Education and Unemployment as Predictors of Terrorism. Political Department, New York University.

Schock, K. (1996). The impact of political opportunities on the relationship between economic inequality and violent political conflict. Journal of Conflict Resolution, 40(1), 98-133.

Shah, M. H., \& Faiz, M. (2015). Terrorism and foreign direct investment: an empirical analysis of saarc countries. City University Research Journal, 6, 219-233.

Shahbaz, M. (2013). Linkage between inflation, economic growth and terrorism in Pakistan. Economic Modelling, 32, 496-506.

Shahbaz, M., \& Shabbir, M. S. (2011). Is hike in inflation responsible for terrorism in Pakistan? MPRA Paper, 1-44. 